\title{
EXPORT ENTRY AND EXIT \\ BY GERMAN FIRMS
}

Andrew B. Bernard

Joachim Wagner

Working Paper 6538 


\title{
EXPORT ENTRY AND EXIT \\ BY GERMAN FIRMS
}

\author{
Andrew B. Bernard \\ Joachim Wagner
}

Working Paper 6538

http://www.nber.org/papers/w6538

\section{NATIONAL BUREAU OF ECONOMIC RESEARCH 1050 Massachusetts Avenue \\ Cambridge, MA 02138 \\ April 1998}

Special thanks go to Uwe Rode and the Statistical Office of Lower Saxony for providing access to the data and running the statistical programs. Thanks also to the Industrial Performance Center at MIT for research support. All errors are ours. Any opinions expressed are those of the authors and not those of the National Bureau of Economic Research.

(C) 1998 by Andrew B. Bernard and Joachim Wagner. All rights reserved. Short sections of text, not to exceed two paragraphs, may be quoted without explicit permission provided that full credit, including (C) notice, is given to the source.

Export Entry and Exit by German Firms 
Andrew B. Bernard and Joachim Wagner

NBER Working Paper No. 6538

April 1998

JEL Nos. F20, D21, L60

\section{ABSTRACT}

This paper examines the decision to enter the export market by German firms. While exports have played an important role in recent German business cycle movements, little is known about the export supply response of German firms. This paper presents a dynamic model of the export decision by a profit-maximizing firm. Using a panel of German manufacturing plants, we test for the role of plant characteristics and sunk costs in the entry decision. We find evidence for substantial sunk costs in export entry; exporting today by a plant increases the probability that the plant will export tomorrow by $50 \%$. This advantage depreciates quickly, falling by two thirds in a year. We also find evidence that plant success, as measured by size and productivity, increases the likelihood of exporting.

Andrew B. Bernard

Yale School of Management

135 Prospect Street

New Haven, CT 06511

and NBER

andrew.bernard@yale.edu
Joachim Wagner

Institut für Volkswirtschaftslehre

Universität Lüneburg

D-21332 Lüneburg

GERMANY 


\section{Introduction}

As with several past episodes, the recent uptick in the business cycle in Germany appears to be driven largely by exports. While German GDP increased by $1.8 \%$ per year from 1993 to 1997, German exports increased $7.0 \%$ per year over the same period, accounting for all the increase in aggregate output. At the same time, while exchange rates with other European nations were relatively stable in advance of the expected adoption of monetary union, on a trade-weighted basis the mark was depreciating, by 6\% from January 1995 to January 1998. The decline against the dollar was substantially larger, $17 \%$ over the same period. To understand how much of the export (and output) growth was driven by these exchange rate movements, we must first understand the responses of German firms to external shocks. In this paper we use a unique longitudinal data set for a large number of manufacturing establishments in Germany to demonstrate what firm characteristics are important for export entry and to investigate the magnitude of the sunk costs of starting to export.

Large changes in exchange rates are hypothesized to have significant effects on the trade flows of a country. However, the timing and magnitude of these changes in the short run are in part determined by the ability of firms to adjust their output in response to the changes in relative prices. Aggregate output changes result from two related but distinct activities by firms. First, existing exporters can increase their export intensity. This may result either from a redirection of output destined for the domestic market to foreign customers or from an overall increase in production coupled with an expansion of exports. The alternative mechanism for the export response is through entry of existing or new firms into the export market. In this paper we examine this latter channel of entry into the export market. We consider what firm characteristics are important for entry as well as the magnitude of the sunk costs of starting exporting.

The role of exporting economic performance and economic growth in particular has been a topic of research for many years. In recent years, the advent of large microeconomic data sets for a variety of countries, both developed and less-developed, has led to a resurgence of work attempting to understand the causal nature between exporting and firm performance. Bernard and Jensen (1998) show that U.S. exporters have faster sales and employment growth than non-exporters in the same industry but do not have faster 
productivity growth. They also find that there are large ex-ante advantages in terms of both growth rates and levels for future exporters. Bernard and Wagner (1997) study the relationship between firm success and exporting in German plants and also find that high productivity, large firms are more likely to become exporters ex-ante but do not outperform non-exporters after entry. In a sample of three developing countries, Clerides, Lach, and Tybout (1997) also find that exporting does not lower average variable cost relative to non-exporters. They also find some evidence that low cost firms are more likely to enter.

The literature on exporting and firm performance has also considered the role of entry costs in the export decision. Roberts and Tybout (1997) model the entry decision by Colombian firms and using an empirical strategy based on a dynamic probit with plant random effects conclude that there are substantial entry costs. In their sample, prior exporting experience can increase the probability of exporting by as much as 60 percentage points. They also find that larger, older plants that are part of a multi-plant firm are more likely to export. Bernard and Jensen (1997) employ a linear probability framework with fixed plant effects and also find substantial sunk costs in export entry. Export experience in the previous year increases the probability of exporting by $40 \%$, although the entry advantage depreciates very quickly. Bernard and Jensen (1998) find that larger, high wage, and more productive plants are more likely to enter as are plants that have recently changed their product line.

In this paper we consider the role of sunk costs and plant characteristics in the export entry decision by German plants in Lower Saxony. We start by documenting the aggregate relationship between real exchange rate changes and movements in and out of the export market by German plants. The results are not unexpected, as the mark appreciates, exit rates increase and entry rates decline. Conversely, depreciations not only lead to increasing ratios of exports to sales but also induce entry. However, the magnitudes of the entry and exits are not large, so we are led to suspect that there are substantial costs associated with the decision. To determine the likelihood that entry occurs after a favorable exchange rate shock, we write down a model of entry into the export market and estimate the magnitudes of the sunk costs. We find that current exporting increases the probability of future exporting by $50 \%$. The longer firms are out of the export market, the smaller the benefit of past export experience. In addition, we find that successful plants, as 
measured by size or productivity, are more likely to become exporters, as are plants with greater shares of skilled workers.

In the next section, we describe our sample of plants and outline the differences between exporters and non-exporters. Section 3 discusses the extent of entry and exit by plants in Lower Saxony during the 1980s and the aggregate movements in exchange rates and output. In section 4, we present the model of the decision to export. Section 5 discusses alternative methodologies for estimating the binary panel data model with firm effects and Section 6 contains the estimation results. Section 7 concludes.

\section{Exporters and Non-exporters in Lower Saxony}

We start by describing our sample of plants and the differences between exporters and non-exporters. ${ }^{1}$ The data come from an annual survey of manufacturing establishments conducted in Germany. However, due to the confidentiality requirements under German law, permission of the State government is required for use of any micro data. To date, only the state of Lower Saxony has permitted researchers to make use of the data. ${ }^{2}$ We employ an unbalanced panel of 7,624 German manufacturing plants in Lower Saxony from an annual survey of all establishments with 20 or more employees. Data coverage includes employment, value of shipments, value of exports, annual wages by two categories of workers, production worker hours, investment values, and value of production.

Table 1 contains means by export status (exporter/non-exporter) for each year in the sample. The fraction of plants exporting ranged from a low of $38 \%$ in 1981 to $47 \%$ by 1991 . In 5 of the 14 years, net flows of plants into exporting were negative. The share of output shipped abroad by the average exporting plant in the sample moved in a relatively narrow range from $18.03 \%$ in 1978 to a peak of $22.15 \%$ in 1987 and 1988 .

Table 1 also shows some of the cross-sectional differences between exporters and non-exporters. As found in every study of exporting, the most

${ }^{1}$ See Bernard and Wagner (1997) for more information on the performance of exporters and non-exporters in the panel.

${ }^{2}$ Thus we caution that our results may not be comparable for other German states. However, as of now there is no basis for comparison. See the appendix in Bernard and Wagner (1997) for more information on the construction of the data. Also see Methner (1992). 
striking difference between exporters and non-exporters is their relative size. Exporters in Lower Saxony are more than twice as large as non-exporters and have higher labor productivity as well. Exporters paid their blue collar workers $25 \%$ more per hour on average than non-exporters, while white collar workers earned salaries $22 \%$ greater at exporting plants. The fraction of blue collar workers in the total workforce was about three quarters for both exporters and non-exporters. ${ }^{3}$

\section{$3 \quad$ Entry and Exit}

In this section, we consider the role of exchange rate changes in determining the export entry and exit patterns of the German plants. Table 2 contains a detailed breakout of entry and exit by year for plants in the sample. Plants are divided into four categories, continuing exporters, non-exporters, entrants and exits. As shown in Figure 1, entry and exit rates are negatively correlated over the period with a correlation coefficient of -0.35 , significant at the $1 \%$ level. This is especially true for 1985 and 1988 which were years of substantial entry and lower exit. Export intensity and entry go hand in hand as is shown in Figure 2. Years of substantial entry by new exporters are also years in which existing exporters increase the fraction of shipments going abroad.

The natural explanation for the variation in entry, exit and intensity is fluctuations in the real exchange rate. Figures 3 and 4 show the variation in the real exchange rate $(\$ / D M 1972=100)$ and entry and intensity respectively. Correlations for both export measures are strongly negative and significant, -0.61 and -0.75 respectively. As one might expect if there are sunk costs in entering, but not in expanding export shipments, the real exchange rate effects are larger for export intensity than for entry rates. Interestingly, the correlations between lagged values of the real exchange rate and export entry are not significant, suggesting alternatively that sunk costs might not be as important for German firms. However, these aggregate numbers do not let us disentangle firm specific factors from aggregate shocks. To do this we first review a model of entry with sunk costs in the next section.

\footnotetext{
${ }^{3}$ These numbers differ slightly from those reported in Bernard and Wagner (1997) which were for the years 1978 and 1992 .
} 


\section{Modelling the Export Decision}

The theoretical literature on sunk costs and exporting is developed in papers by Dixit (1989a,b), Baldwin (1988), Baldwin and Krugman (1989), and Krugman (1989). Roberts and Tybout (1997) and Bernard and Jensen (1997) empirically address the question of entry and exit costs in the decision to export by the profit maximizing firm.

We follow Roberts and Tybout (1997) and Bernard and Jensen (1997) in modelling the decision to export by the rational, profit-maximizing firm as analogous to the decision to market a new product. The firm considers expected profits today and in the future from the decision to enter the foreign market net of any fixed costs.

We assume that the firm is always able to produce at the profit-maximizing level of exports, $q_{i t}^{*}$, if it enters the foreign market. In the one period case with no entry costs, the firm receives profits

$$
\pi_{i t}\left(X_{t}, Z_{i t}\right)=p_{t} \cdot q_{i t}^{*}-c_{i t}\left(X_{t}, Z_{i t} \mid q_{i t}^{*}\right)
$$

where $p_{t}$ is the price of goods sold abroad and $c_{i t}(\cdot)$ is the variable cost of producing quantity $q_{i t}^{*}$. Exogenous factors affecting profitability, such as exchange rates, are denoted as $X_{t}$, while firm-specific factors are denoted by $Z_{i t}{ }^{4}$ Firm characteristics that might increase the probability of exporting include size, labor composition, productivity, product mix, and ownership structure.

If expected profits are greater than zero, then the firm will export. The export status of firm $i$ in period $t$ is given by $Y_{i t}$, where

$$
\begin{aligned}
& Y_{i t}=1 \text { if } \pi_{i t} \geq 0 \\
& Y_{i t}=0 \text { if } \pi_{i t}<0
\end{aligned} .
$$

Extensions of the single period model to multiple periods is fairly straightforward when there are no entry costs. The expected profits of the firm become

$$
\Pi_{i t}\left(X_{t}, Z_{i t}\right)=\mathrm{E}_{t}\left(\sum_{s=t}^{\infty} \delta^{s-t}\left[p_{s} q_{i s}^{*}-c_{i s}\left(X_{s}, Z_{i s} \mid q_{i s}^{*}\right)\right]\right) .
$$

${ }^{4}$ Prices faced by the firm presumably depend on $X_{t}$ and possibly on elements in $Z_{i t}$ as well, i.e. $p_{t}=p_{t}\left(X_{t}, Z_{i t}\right)$. To simplify notation, we write prices as $p_{t}$ throughout. 
As long as the cost function does not depend on the level of output in a previous period, the solution of this multi-period problem is identical to the single period case.

It is natural to think of costs associated with entering foreign markets that may have the character of being sunk in nature. These might include the cost of information about demand conditions abroad, the costs of establishing a distribution system, or the search costs of identifying local bankers and transport companies. ${ }^{5}$ We refer to these as entry costs and, for ease of exposition, we assume these costs recur in full if the firm exits the export market for any amount of time. ${ }^{6}$ Profits for the firm in single period maximization problem with entry costs are given by

$$
\tilde{\pi}_{i t}\left(X_{t}, Z_{i t}, Y_{i t-1}\right)=p_{t} q_{i t}^{*}-c_{i t}\left(X_{t}, Z_{i t} \mid q_{i t}^{*}\right)-N \cdot\left(1-Y_{i t-1}\right)
$$

where $N$ is the entry cost for the firm. The firm does not have to pay the entry cost if it exported in the previous period, i.e. if $Y_{i t-1}=1$. Firms will export if expected profits net of entry costs are positive, $Y_{i t}=1$ if $\tilde{\pi}_{i t}>0$.

Incorporating entry costs in a dynamic framework provides a means for today's export decision by the firm to influence future decisions to export. This formulation of entry costs as sunk costs yields an option value to waiting and thus increases the region where the firm chooses not to act. The firm chooses a sequence of output levels, $\left\{q_{i s}^{*}\right\}_{s=t}^{\infty}$, that maximizes current and discounted future profits,

$$
\Pi_{i t}=\mathrm{E}_{t}\left(\sum_{s=t}^{\infty} \delta^{s-t}\left[\tilde{\pi}_{i s} \cdot Y_{i s}\right]\right),
$$

where period-by-period profits are given by equation 4 and, as usual, are constrained to be non-negative since the firm always has the option not to export. This is equivalent to the firm choosing whether to export in each period since we allow the firm to always pick the within-period profit

${ }^{5}$ Interviews by the first author with small U.S. manufacturers suggest that distribution networks and financing arrangements represent sizable one-time costs in terms of time and money.

${ }^{6}$ In our empirical work, we test whether these entry costs recur fully after one period or whether there is some persistent benefit from having exported more than one year in the past. 
maximizing quantity. The value function is the same as before with the addition of potential entry costs in the within period profits,

$$
V_{i t}(\cdot)=\max _{\left\{q_{i t}^{*}\right\}}\left(\widetilde{\pi}_{i t} \cdot\left[q_{i t}^{*}>0\right]+\delta \mathrm{E}_{t}\left[V_{i t+1}(\cdot) \mid q_{i t}^{*}\right]\right) .
$$

A firm will choose to export in period $t$, i.e. $q_{i t}^{*}>0$, if

$$
\begin{array}{r}
p_{t} q_{i t}^{*}+\delta\left(\mathrm{E}_{t}\left[V_{i t+1}(\cdot) \mid q_{i t}^{*}>0\right]-\mathrm{E}_{t}\left[V_{i t+1}(\cdot) \mid q_{i t}^{*}=0\right]\right) \\
>c_{i t}+N_{i t} \cdot\left(1-Y_{i t-1}\right) .
\end{array}
$$

The difference in the multi-period models with and without entry costs comes through the added intertemporal link between exporting today and exporting tomorrow embodied in the cost of entry.

While we choose to think about the export decision as the introduction of a new good, one might imagine that firms choose total production quantities regardless of the intended destination. Only after production do firms then decide which market, domestic or foreign, will yield the highest profits. This plausible alternative approach to exporting yields almost identical implications for the value function given above and for our estimation strategy with the notable exception that sunk costs should be negligible.

\section{$5 \quad$ Empirical Methodology}

From the multi-period model with entry costs given in section 4, we find that a firm exports if current and expected revenues are greater than costs,

$$
Y_{i t}=\left\{\begin{array}{cc}
1 & \text { if } \widehat{\pi}_{i t}>c_{i t}+N \cdot\left(1-Y_{i t-1}\right) \\
0 & \text { otherwise }
\end{array}\right.
$$

where

$$
\widehat{\pi}_{i t} \equiv p_{t} q_{i t}^{*}+\delta\left(\mathrm{E}_{t}\left[V_{i t+1}(\cdot) \mid q_{i t}^{*}>0\right]-\mathrm{E}_{t}\left[V_{i t+1}(\cdot) \mid q_{i t}^{*}=0\right]\right) .
$$

Our goal is to identify and quantify factors that increase the probability of exporting. We estimate these effects using a binary choice non-structural approach of the form

$$
Y_{i t}=\left\{\begin{array}{lc}
1 & \text { if } \beta X_{i t}-N \cdot\left(1-Y_{i t-1}\right)+\varepsilon_{i t}>0 \\
0 & \text { otherwise }
\end{array} .\right.
$$

Plant characteristics are included in the vector $X_{i t}$, while other factors such as terms of trade shocks are incorporated in the residual, $\varepsilon_{i t}$. 


\subsection{Experience and Entry Costs ${ }^{7}$}

The most difficult issue in the estimation of equation 10 concerns the identification of the parameter on the lagged endogenous variable. It is highly likely that there are unobserved characteristics such as product attributes or managerial ability which affect the decision to export by the firm. Since these characteristics are potentially permanent, or at least highly serially correlated, and unobserved by the econometrician, they will induce persistence in export behavior, either in or out of the market, and thus will cause us to overestimate the entry costs and experience effects discussed above. ${ }^{8}$ In practice this means that the error term, $\varepsilon_{i t}$, can be thought of as comprising two components, a permanent plant-specific element, $\kappa_{i}$, and a transitory component, $\eta_{i t}$, which captures other, exogenous shocks.

There are several potential estimation strategies for this dynamic binary choice framework with unobserved heterogeneity, including probit with random effects, and linear probability models with fixed or random effects. The use of random effects requires that the plant effects be uncorrelated with the regressors. The required assumption for random effects is quite likely violated in our export decision model as plant characteristics such as size, wage levels, and ownership characteristics are apt to be correlated with product attributes, managerial ability, technology and other unobserved plant effects. Roberts and Tybout (1997), however, use a random effects probit specification in their analysis of sunk costs and entry. Most fixed effects models, on the other hand, produce biased and inconsistent parameter estimates, especially for the coefficient on the lagged dependent variable. Bernard and Jensen (1997) opt for a fixed effects linear probability model and attempt to control for the problem of a lagged endogenous variables by estimating the model in first differences with instrumental variables.

In this paper, we consider results from both a random effects probit specification and a linear probability model with fixed effects. The linear probability framework is given by

$$
Y_{i t}=\beta X_{i t-1}+\theta Y_{i t-1}+\varepsilon_{i t},
$$

\footnotetext{
${ }^{7}$ This and the following subsections draw heavily on the discussion in Bernard and Jensen (1997b).

${ }^{8}$ See Heckman (1981) for an analysis of the theoretical issues and Roberts and Tybout (1997) and Bernard and Jensen (1997) for discussions in the exporting context.
} 
while the random effects probit setup is

$$
Y_{i t}=\left\{\begin{array}{cc}
1 & \text { if } \beta X_{i t}-\theta Y_{i t-1}+\kappa_{i}+\mu_{i t}>0 \\
0 & \text { otherwise }
\end{array} .\right.
$$

We proceed in several steps. First, we estimate equation 11 in levels, ignoring any plant effects. The levels specification gives us an upper bound on the importance of sunk costs. ${ }^{9}$ Bernard and Jensen (1998) and Bernard and Wagner (1997) show that plants switching export status from non-exporter to exporter, and vice versa, undergo dramatic contemporaneous changes in size, employment composition, and wages. However, the direction of the causality remains uncertain in that analysis so we lag all plant characteristics and other exogenous variables one year to avoid possible simultaneity problems.

Next, we explicitly consider the role of permanent plant effects, $\kappa_{i}$, as in

$$
Y_{i t}=\beta X_{i t-1}+\theta Y_{i t-1}+\kappa_{i}+\eta_{i t}
$$

We estimate equation 13 first in levels, i.e., fixed effects, and then in differences. The fixed effects estimates are almost surely biased downwards and inconsistent but give us a lower bound for the importance of the lagged endogenous variable. For the specification in first differences, we employ an instrumental variables estimator and use two lags of the levels of the right hand side variables as instruments, i.e. $\left(X_{i t-2}, X_{i t-3}, Y_{i t-2}, Y_{i t-3}\right)$,

$$
\Delta Y_{i t}=\beta \Delta X_{i t-1}+\theta \Delta Y_{i t-1}+\Delta \eta_{i t} .
$$

This specification avoids the serious problem of inconsistent estimates found in the fixed effects model. ${ }^{10}$ However, the IV specification introduces the potential problem that instruments perform poorly.

The probit specification in 12 also assumes that the errors, $\varepsilon_{i t}$, are comprised of a permanent plant-specific element and a purely transitory component, $\varepsilon_{i t}=\kappa_{i}+\eta_{i t}$. The permanent component, $\kappa_{i}$, is assumed to be uncorrelated across plants, $\operatorname{cov}\left(\kappa_{i}, \kappa_{j}\right)=0$, and the transitory component, $\eta_{i t}$, uncorrelated across time, $\operatorname{cov}\left(\eta_{i t}, \eta_{i t-s}\right)=0$. These assumptions transform the problem into a dynamic random effects probit, after assuming that the

\footnotetext{
${ }^{9}$ The levels specification also allows us to observe the effects of time-invariant plant attributes on export probabilities. Any variables that do not change over time, such as multinational status, will be perfectly correlated with the fixed effect.

${ }^{10}$ See Holtz-Eakin, Newey, and Rosen (1988) and Keane and Runkle (1992).
} 
errors are normally distributed. One final, and important, problem remains in that the initial period export status, $Y_{i 0}$, is not exogenous if there are permanent plant-specific components in the error term. Ideally, one would instrument for these initial values

$$
\widehat{Y}_{i 0}=f\left(X_{i,-1}, Z_{i,-1}\right)+\xi_{i 0}
$$

allow the errors to be correlated with the permanent plant-specific error, $\operatorname{cov}\left(\kappa_{i}, \xi_{i 0}\right)=\rho_{1}$. Given the lack of appropriate instruments we have run the probit assuming the initial conditions are exogenous.

\subsection{Plant Characteristics}

Drawing on the cross-sectional comparisons of exporters and non-exporters above and elsewhere, we consider several hypotheses about the role of plant characteristics in the export decision. Perhaps the most obvious plant attributes to consider are those related to past success. It would appear to be relatively uncontroversial to claim that good firms become exporters, however, a substantial fraction of export policy assumes instead that exporters become good firms. The measures of plant success we consider include size and productivity. Consistently in all samples and time periods, exporters are much larger plants. Size may proxy for several effects; larger firms by definition have been successful in the past, but size may be associated with lower average, or marginal, costs, providing a separate mechanism for size to increase the likelihood of exporting. We use productivity, measured by value-added per employee, as an additional measure of plant success.

We also consider the role of labor quality. If exported goods are of higher quality and thus have a higher value to weight ratio, then we would expect the quality of the workforce to be positively related with entrance into foreign markets. To proxy for workforce quality, we use lagged average wages and the ratio of white collar to total employees. We also include a dummy for plants that belong to a multi-plant firm to allow for some degree of ownership effects in the decision to export.

\section{Empirical Results}

We estimate all our various specifications on an unbalanced panel which averages 9 years of data for more than 6400 plants totalling over 57,600 ob- 
servations for the regressions in levels and over 51,000 for the first differences specification. ${ }^{11}$ We divide the results into two sections. First we report specifications without controlling for any form of individual plant effect and then we consider the various methods of absorbing the individual heterogeneity. The first set of results allows us to examine the effects of time-invariant plant attributes, while the latter does not.

The baseline specification contains the plant characteristics mentioned above. These are plant size (employment), productivity (output per worker), labor force characteristics (average wage and white collar/total workers), and ownership (a multi-plant firm dummy). The proxies for sunk costs of entry are the coefficients on two measures of past export participation, export status in the previous year, and a dummy for whether the plant exported two years ago but not last year. This last measure allows us to capture the possibility that the capital expended in entering the export market does not depreciate immediately upon exiting. ${ }^{12}$

\subsection{Estimates without plant effects}

Table 3 contains estimates without controlling for plant heterogeneity.. Results from the linear probability model are given in column 1 and those from the probit model are in column 2. The results confirm the hypothesis that successful plants are more likely to enter the export market. The coefficients on size and productivity are significant in both specifications at the $1 \%$ level. The magnitudes do vary across the two estimation methodologies with all the coefficients much stronger in the probit results. The evidence on the importance of labor force characteristics also generally confirm that plants with higher wages and more skilled workers are more likely to export. The wage effects, however, are not significant and are the wrong sign in the linear probability framework. Surprisingly, plants that are a part of a multi-plant firm are significantly less likely to export than other plants. This is the opposite of findings by Bernard and Jensen (1997) for the U.S..

The estimates of sunk costs in these specifications without controlling for unobserved heterogeneity are immense. The point estimates in both cases exceed 0.84. Taken at face value, this would suggest that current exporters

\footnotetext{
${ }^{11}$ Actual samples sizes may vary depending on the lag length chosen, however, none of the results are sensitive to the years included.

${ }^{12}$ It is preferable to think of this capital as information rather than physical investment.
} 
are 80-90\% more likely to export next year than are non-exporters. The coefficient on the measure of export status two years hence are also positive, significant and in the case of the probit model, quite large. ${ }^{13}$ Being out of the export market for a year does reduce the entry benefits of having once participated. The point estimates of the extent of the depreciation are $85 \%$ and $55 \%$ for two specifications. Based on these results one would conclude there are substantial sunk costs to entry and they depreciate substantially in a year, but not completely. However, as discussed above, these estimates incorporate any persistent unobserved heterogeneity and should be considered extreme upper bounds on the importance of sunk costs in the decision to export by German firms.

\subsection{Estimates with plant effects}

Table 4 contains our preferred estimates including several different methods for controlling for the unobserved components of the error term. Column 1 contains estimates from a linear probability model estimated in levels with plant fixed effects. Column 2 estimates a linear specification in first differences with lagged levels as instruments. The random effects probit results are presented in column 3 with the associated probability changes given in column 4.

The linear probability model in levels with plant fixed effects most likely overcontrols for unobserved plant heterogeneity and yields estimates of sunk costs that are biased downwards. ${ }^{14}$ As before, measures of plant success, size and productivity, are significant predictors of future export status, as is the share of white collar workers at the plant. The new estimates on the magnitude of the sunk costs are dramatically lower than those without plant effects in the error. The one year ahead probability increase from being an exporter today is less than half as large, $38.0 \%$, while the benefit of having been in two years previously is only $1.8 \%$. The important fact is that both numbers are significant and positive. The likely downward bias in this set of results means that we can safely conclude that there are indeed sunk costs

${ }^{13}$ Remember that this measure is actually a dummy which is one if the plant last exported two years ago.

${ }^{14}$ See Bernard and Jensen (1997) for a detailed discussion of this problem in the case of entry into exporting. 
of entering the export market that yield increases in probability in the range of $38 \%-85 \%$.

Turning to the IV first differences specification in column 2, we find again that the past export measures are significant and positive. Exporting today increase the probability of exporting tomorrow by $52 \%$ while fully two thirds of that benefit depreciate in one year. The other plant characteristics in the IV-FD specification are generally not significant, with the exception of size that shows up with the wrong sign at the $10 \%$ level. The poor performance of the plant characteristics may be due partly to the nature of the instruments used..$^{15}$

Finally we consider the random effects probit results. Here we again find strong, positive and significant effects of past exporting on current export status. Exporting today increases the probability of being an exporter tomorrow by $68 \%$ and the effect shows far less depreciation $(42 \%)$ than in other specifications.. In this framework, the plant effects are again significant and in the expected directions, with measure of success, especially productivity, being strongly correlated with future export status. Bernard and Jensen (1997) discuss potential problems with the random effects estimators that might lead to an overestimate of sunk costs. Looking over the entire set of results, we suspect this might be only a relatively small problem in the German data as the similarity of the IV-FD specification and the random effects probit estimates is quite striking.

\section{Conclusions}

This paper provides another round of evidence on the relationship between success and exporting at the plant or firm level. We have focussed our attention on the role that plant characteristics play in determining which firms enter and the magnitude of the costs, or barriers, that German firms face in deciding to begin exporting.

Our results from a dynamic binary choice model of the decision to enter provide strong support that there are substantial sunk costs for export entry. The range, estimated as the decreased probability of entering if the firm is out of the market today, run between $38 \%$ and $89 \%$. The most reasonable point

\footnotetext{
${ }^{15}$ The instruments perform much better for predicting switches export status than employment and productivity changes.
} 
estimates, however, suggest a magnitude on the order of just over $50 \%$. These results are in between those estimated using U.S. (Bernard and Jensen 1997) and developing country data (Roberts and Tybout 1997), with U.S. firms apparently facing the lowest sunk costs to exporting. The capital needed to enter the market does not depreciate entirely after one period, although our preferred estimates suggest that as much as two thirds has dissipated in a year.

The results confirm that good plants are much more likely to become exporters. Measures of size and productivity are positive and significant in most specifications. In addition, plants intensive in skilled workers are more likely to export. This provides independent evidence for the growing literature on the relationship between exporting and success. While exporters have desirable performance characteristics when compared to non-exporters in almost every industry and country, ${ }^{16}$ the growing consensus, confirmed in our results, is that success leads to exporting rather than exporting leading to success.

The results in this paper suggest an important area of future research is the measurement of the various components of sunk costs of export entry and the extent to which they take on the characteristics of public goods. In addition, further work is needed on how the increasing economic integration in Europe will affect cross-border activities by German and other firms.

${ }^{16}$ See Bernard and Jensen (1998) and Bernard and Wagner (1997). 


\section{References}

Baldwin, Robert. (1988) "Hysteresis in Import Prices: The Beachhead Effect." American Economic Review, 78(4) pp.773-785.

Baldwin, Robert and Paul Krugman. (1989) "Persistent Effects of Large Exchange Rate Shocks." Quarterly Journal of Economics, Vol. 104, No. 4 pp. 635-654.

Bernard, Andrew B. and J. Bradford Jensen. (1997). "Why Some Firms Export: Experience, Entry Costs, Spillovers, and Subsidies." Yale mimeo.

Bernard, Andrew B. and J. Bradford Jensen. (1998). "Exceptional Exporter Performance: Cause, Effect, or Both?." Journal of International Economics forthcoming.

Bernard, Andrew B. and Joachim Wagner. (1997). "Exports and Success in German Manufacturing." Weltwirtschaftliches Archiv, 133(1), 134-157.

Clerides, Sofronis, Saul Lach and James Tybout. (1997) "Is "Learningby-Exporting" Important?" NBER Working Paper No. 5717.

Dixit, Avinash. (1989a) "Entry and Exit Decisions Under Uncertainty." Journal of Political Economy, Vol. 97, No. 3 pp. 620-638.

Dixit, Avinash. (1989b) "Hysteresis, Import Penetration, and Exchange Rate Pass-Through." Quarterly Journal of Economics, Vol. 104, No. 2 pp. 205-228.

Heckman, James. (1981) "The Incidental Parameters Problem and the Problem of Initial Conditions in Estimating a Discrete Time-Discrete Data Stochastic Process." in Charles Manski and Daniel McFadden (eds.), The Structural Analysis of Discrete Data. Cambridge: MIT Press.

Holtz-Eakin, Douglas, Whitney Newey, and Harvey Rosen. (1988) "Estimating Vector Autoregressions in Panel Data." Econometrica, Vol. 56, No. 6, pp 1371-1395. 
Keane, Michael and David Runkle (1992) "On the Estimation of Panel-Data Models with Serial Correlation When Instruments Are Not Strictly Exogenous." Journal of Business and Economic Statistics, Vol. 10, No. 1 pp. 1-29.

Krugman, Paul. (1989) Exchange Rate Instability. MIT Press, Cambridge MA.

Krugman, Paul. (1992) Geography and Trade. MIT Press, Cambridge MA.

Methner, E. (1992). Das Erhebungsprogramm der amtlichen Statistik im Bereich des Produzierenden Gewerbes. In R. Ertel and J. Wagner (eds.), Produzieren in Niedersachsen. Empirische Untersuchungen mit Betriebsdaten. NIW-Vortragsreihe 6. Hanover: NIW.

Roberts, Mark and James Tybout. (1997). "The Decision to Export in Columbia: An Empirical Model of Entry with Sunk Costs." American Economic Review, 87(4), 545-564. 
Table 1: Exporters and Non-Exporters

\begin{tabular}{|c|c|c|c|c|c|c|c|c|c|c|c|}
\hline Year & Status & $\begin{array}{l}\text { No. of } \\
\text { firms }\end{array}$ & $\begin{array}{l}\text { Export quota } \\
\text { (percent) }\end{array}$ & $\begin{array}{c}\text { Hours per } \\
\text { worker - blue } \\
\text { collar workers }\end{array}$ & $\begin{array}{l}\text { Hourly wages } \\
\text { blue collar } \\
\text { workers (DM; } \\
\text { real, 1985) }\end{array}$ & $\begin{array}{l}\text { Salaries - } \\
\text { White Collar } \\
\text { (1000 DM; } \\
\text { real, 1985) }\end{array}$ & $\begin{array}{c}\text { No. of } \\
\text { employees }\end{array}$ & $\begin{array}{c}\text { Fraction of } \\
\text { blue collar } \\
\text { workers }\end{array}$ & $\begin{array}{l}\text { Sum of sales } \\
\text { in Germany } \\
\text { (1000 DM; } \\
\text { real, 1991) }\end{array}$ & $\begin{array}{c}\text { Exports (1000 } \\
\text { DM; real, } \\
1991)\end{array}$ & $\begin{array}{l}\text { Value of } \\
\text { production } \\
\text { (1000 DM; } \\
\text { real, 1991) }\end{array}$ \\
\hline \multirow[t]{2}{*}{78} & 0 & 2853 & & 1876 & 16.59 & 42.74 & 53.50 & 0.75 & 10869 & & 9583 \\
\hline & 1 & 1798 & 18.03 & 1717 & 21.18 & 51.99 & 278.45 & 0.75 & 42615 & 20006 & 50344 \\
\hline \multirow[t]{2}{*}{79} & 0 & 2845 & & 1849 & 17.29 & 44.19 & 54.31 & 0.75 & 11269 & & 9955 \\
\hline & 1 & 1791 & 18.24 & 1707 & 21.70 & 53.11 & 280.91 & 0.75 & 44339 & 21447 & 52201 \\
\hline \multirow[t]{2}{*}{80} & 0 & 2796 & & 1828 & 17.44 & 44.64 & 55.31 & 0.75 & 11457 & & 9961 \\
\hline & 1 & 1767 & 18.87 & 1680 & 22.41 & 54.41 & 288.27 & 0.74 & 44015 & 23164 & 54018 \\
\hline \multirow[t]{2}{*}{81} & 0 & 2909 & & 1796 & 17.41 & 44.52 & 53.71 & 0.74 & 11248 & & 9932 \\
\hline & 1 & 1780 & 20.10 & 1644 & 22.32 & 54.29 & 279.85 & 0.74 & 42251 & 24509 & 52487 \\
\hline \multirow[t]{2}{*}{82} & 0 & 2754 & & 1776 & 17.30 & 43.85 & 53.08 & 0.73 & 10799 & & 9840 \\
\hline & 1 & 1761 & 20.94 & 1613 & 22.08 & 54.62 & 273.80 & 0.73 & 41020 & 24975 & 51702 \\
\hline \multirow[t]{2}{*}{83} & 0 & 2665 & & 1802 & 17.14 & 44.17 & 52.58 & 0.73 & 11282 & & 9536 \\
\hline & 1 & 1736 & 20.75 & 1648 & 21.88 & 55.11 & 266.52 & 0.73 & 42796 & 24512 & 52394 \\
\hline \multirow[t]{2}{*}{84} & 0 & 2570 & & 1802 & 17.17 & 44.45 & 52.56 & 0.73 & 11366 & & 9517 \\
\hline & 1 & 1745 & 21.75 & 1654 & 22.30 & 55.95 & 262.21 & 0.73 & 42643 & 28544 & 55459 \\
\hline \multirow[t]{2}{*}{85} & 0 & 2397 & & 1780 & 17.49 & 44.67 & 53.27 & 0.73 & 12294 & & 9972 \\
\hline & 1 & 1818 & 21.95 & 1663 & 22.20 & 56.26 & 257.32 & 0.73 & 42198 & 30305 & 56618 \\
\hline \multirow[t]{2}{*}{86} & 0 & 2301 & & 1767 & 18.16 & 46.76 & 55.10 & 0.74 & 12632 & & 10459 \\
\hline & 1 & 1837 & 21.76 & 1698 & 22.77 & 58.58 & 263.83 & 0.73 & 43550 & 28809 & 56833 \\
\hline \multirow[t]{2}{*}{87} & 0 & 2270 & & 1750 & 18.81 & 47.88 & 56.31 & 0.73 & 13361 & & 10657 \\
\hline & 1 & 1800 & 22.15 & 1586 & 24.90 & 60.73 & 263.52 & 0.73 & 45127 & 28686 & 56323 \\
\hline \multirow[t]{2}{*}{88} & 0 & 2179 & & 1776 & 18.97 & 48.85 & 56.35 & 0.72 & 13738 & & 10626 \\
\hline & 1 & 1829 & 22.15 & 1597 & 25.42 & 62.27 & 259.44 & 0.73 & 46687 & 29822 & 57786 \\
\hline \multirow[t]{2}{*}{89} & 0 & 2232 & & 1735 & 19.53 & 49.13 & 57.23 & 0.73 & 14469 & & 11258 \\
\hline & 1 & 1885 & 22.08 & 1581 & 25.79 & 62.72 & 255.87 & 0.73 & 47319 & 32032 & 60188 \\
\hline \multirow[t]{2}{*}{90} & 0 & 2252 & & 1727 & 20.33 & 50.58 & 59.42 & 0.73 & 15655 & & 11982 \\
\hline & 1 & 1900 & 21.12 & 1565 & 26.32 & 64.04 & 261.79 & 0.74 & 51793 & 31347 & 61425 \\
\hline \multirow[t]{2}{*}{91} & 0 & 2248 & & 1706 & 21.06 & 51.35 & 61.85 & 0.74 & 16263 & & 13113 \\
\hline & 1 & 1954 & 19.77 & 1553 & 27.16 & 65.38 & 257.81 & 0.73 & 58104 & 29770 & 63903 \\
\hline \multirow[t]{2}{*}{92} & 0 & 2340 & & 1702 & 21.53 & 52.18 & 60.33 & 0.73 & 16107 & & 12552 \\
\hline & 1 & 1970 & 19.82 & 1556 & 27.82 & 67.10 & 251.00 & 0.72 & 55249 & 27362 & 63702 \\
\hline
\end{tabular}


Table 2: Entry and Exit

\begin{tabular}{|c|c|c|c|c|c|c|}
\hline Year & $\begin{array}{l}\text { No. of Firms } \\
\text { exporting in } t\end{array}$ & $\begin{array}{l}\text { No. of Firms not } \\
\text { exporting in } t\end{array}$ & $\begin{array}{l}\text { No. of Firms } \\
\text { exporting in } \mathrm{t} \\
\text { and } \mathrm{t}-1 \\
(1,1) \\
\end{array}$ & $\begin{array}{l}\text { No. of Firms } \\
\text { exporting in } \mathrm{t} \text { that did } \\
\text { not export in } \mathrm{t}-1 \\
(0,1)\end{array}$ & $\begin{array}{l}\text { No. of Firms not } \\
\text { exporting in } t \text { that did } \\
\text { export in } t-1 \\
(1,0)\end{array}$ & $\begin{array}{c}\text { No. of Firms } \\
\text { not exporting } \\
\text { in } \mathrm{t} \text { and } \mathrm{t}-1 \\
(0,0)\end{array}$ \\
\hline 1978 & 1798 & 2853 & & & & \\
\hline 1979 & 1722 & 2917 & 1625 & 97 & 112 & 2805 \\
\hline 1980 & 1717 & 2966 & 1628 & 89 & 103 & 2863 \\
\hline 1982 & 1720 & 2904 & 1620 & 100 & 84 & 2820 \\
\hline 1983 & 1688 & 2743 & 1569 & 119 & 104 & 2639 \\
\hline 1984 & 1690 & 2622 & 1576 & 114 & 86 & 2536 \\
\hline 1985 & 1742 & 2447 & 1602 & 140 & 78 & 2369 \\
\hline 1986 & 1758 & 2334 & 1645 & 113 & 98 & 2236 \\
\hline 1987 & 1726 & 2296 & 1640 & 86 & 112 & 2184 \\
\hline 1991 & 1862 & 2251 & 1767 & 95 & 88 & 2163 \\
\hline 1992 & 1878 & 2301 & 1795 & 83 & 102 & 2199 \\
\hline
\end{tabular}




\section{Table 3: Estimating the Probability of Entry, No Plant Effects}

\begin{tabular}{|l|l|l|}
\hline & $(1)$ & $(2)$ \\
\hline & LP-OLS & Probit $^{1}$ \\
\hline Last Exported in t-1 & $0.849 * * *$ & $0.895 * * *$ \\
\hline & $(0.007)$ & $(0.006)$ \\
\hline Last Exported in t-2 & $0.128 * * *$ & $0.396 * * *$ \\
\hline & $(0.015)$ & $(0.016)$ \\
\hline Size & $0.021 * * *$ & $0.098^{* * *}$ \\
\hline & $(0.004)$ & $(0.004)$ \\
\hline Productivity & $0.009 * * *$ & $0.023 * * *$ \\
\hline & $(0.002)$ & $(0.005)$ \\
\hline Multi-plant & $-0.015 * * *$ & $-0.089 * * *$ \\
\hline & $(0.003)$ & $(0.008)$ \\
\hline Wage & -0.004 & $0.040 * * *$ \\
\hline & $(0.006)$ & $(0.014)$ \\
\hline Non-production & $0.034 * * *$ & $0.071 * *$ \\
\hline & $(0.011)$ & $(0.025)$ \\
\hline Year Dummies & Yes & Yes \\
\hline Industry Dummies & Yes & No \\
\hline & & \\
\hline
\end{tabular}

\footnotetext{
${ }^{1}$ Coefficients represent the change in probability of exporting due to a one standard deviation increase in the independent variable evaluated at the means of the other variables (or a change from $0-1$ in the case of a dummy variable).
} 
Table 4: Estimating the Probability of Entry, Plant Effects

\begin{tabular}{|c|c|c|c|c|}
\hline & $(1)$ & $(2)$ & (3) & $(4)^{2}$ \\
\hline & LP-FE & LP-FD & REProbit & \\
\hline \multirow[t]{2}{*}{ Last Exported in $\mathrm{t}-1$} & $0.380 * * *$ & $0.518 * * *$ & $3.288 * * *$ & 0.68 \\
\hline & $(0.005)$ & $(0.048)$ & $(0.038)$ & \\
\hline \multirow[t]{2}{*}{ Last Exported in $\mathrm{t}-2$} & $0.018 * * *$ & $0.168 * * *$ & $1.061 * * *$ & 0.40 \\
\hline & $(0.006)$ & $(0.025)$ & $(0.051)$ & \\
\hline \multirow[t]{2}{*}{ Size } & $0.040 * * *$ & $-0.016 *$ & $0.320 * * *$ & 0.01 \\
\hline & $(0.004)$ & $(0.009)$ & $(0.021)$ & \\
\hline \multirow[t]{2}{*}{ Productivity } & $0.009 * * *$ & -0.001 & $0.179 * * *$ & 0.06 \\
\hline & $(0.002)$ & $(0.004)$ & $(0.022)$ & \\
\hline \multirow[t]{2}{*}{ Multi-plant } & -0.008 & & $-0.224 * * *$ & -0.07 \\
\hline & $(0.006)$ & & $(0.041)$ & \\
\hline \multirow[t]{2}{*}{ Wage } & 0.004 & 0.000 & $0.171 * * *$ & 0.02 \\
\hline & $(0.008)$ & $(0.012)$ & $(0.067)$ & \\
\hline \multirow[t]{2}{*}{ Non-production } & $0.036 * *$ & -0.031 & $0.208 *$ & 0.01 \\
\hline & $(0.016)$ & $(0.026)$ & $(0.112)$ & \\
\hline Year Dummies & Yes & Yes & Yes & \\
\hline & & & & \\
\hline
\end{tabular}

\footnotetext{
${ }^{2}$ Coefficients represent the change in probability of exporting due to a one standard deviation increase in the independent variable evaluated at the means of the other variables (or a change from $0-1$ in the case of a dummy variable).
} 


\section{Figure 1: Entry and Exit Rates}

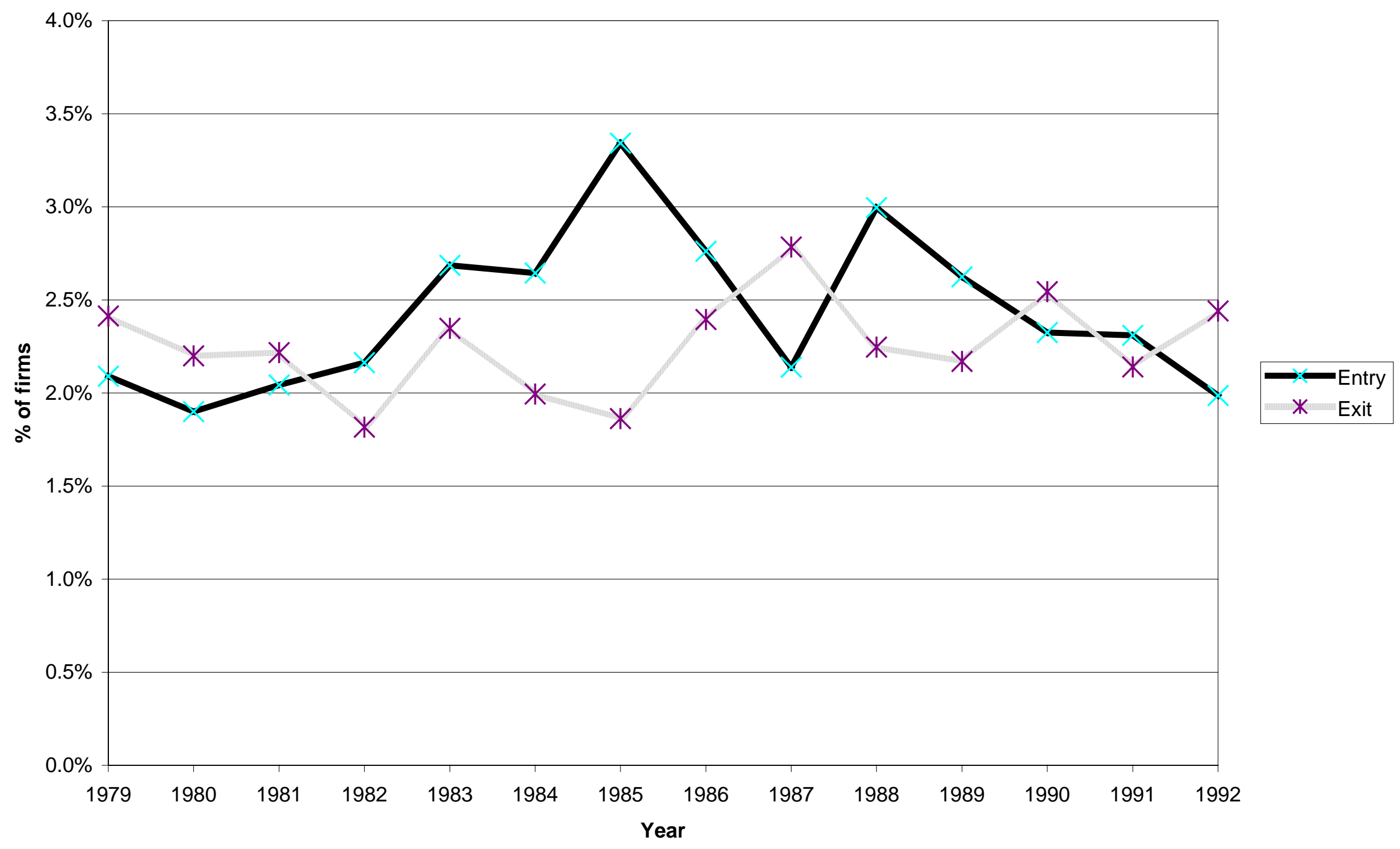


Figure 2: Entry and Intensity

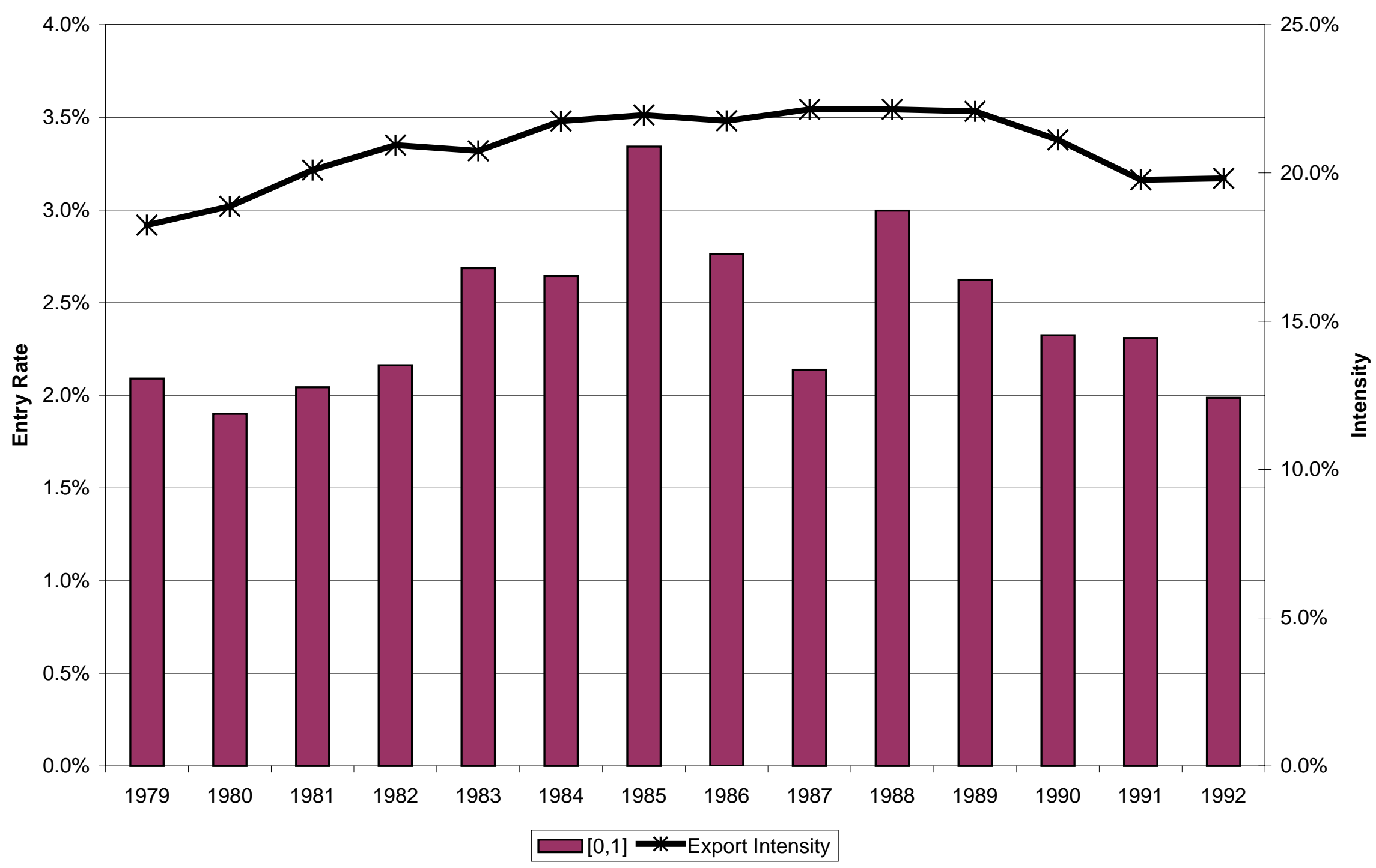


Figure 3: Export Entry and the Real Exchange Rate

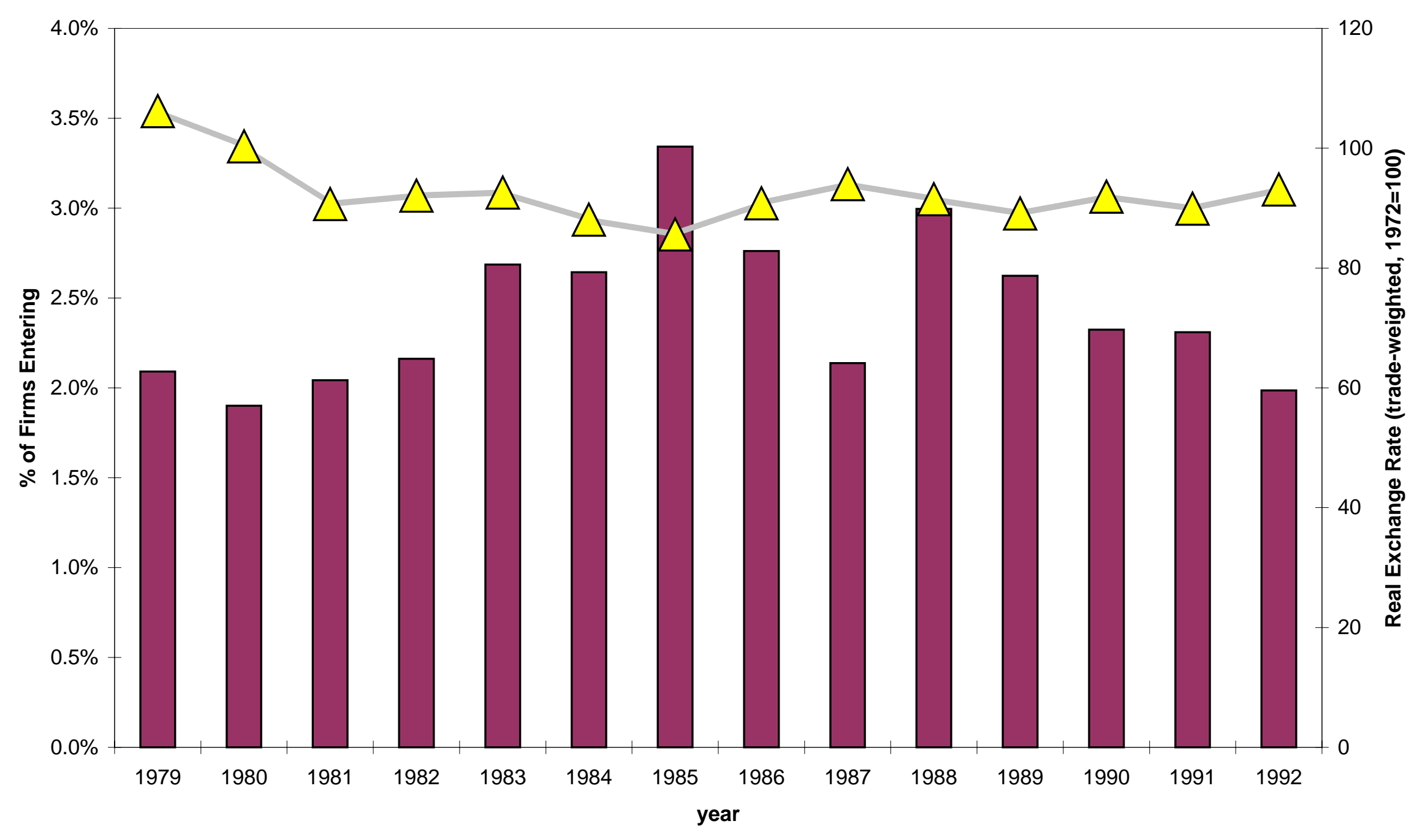

Entry $\triangleq \Delta$ Real Exchange Rate 
Figure 4: Export Intensity and the Real Exchange Rate

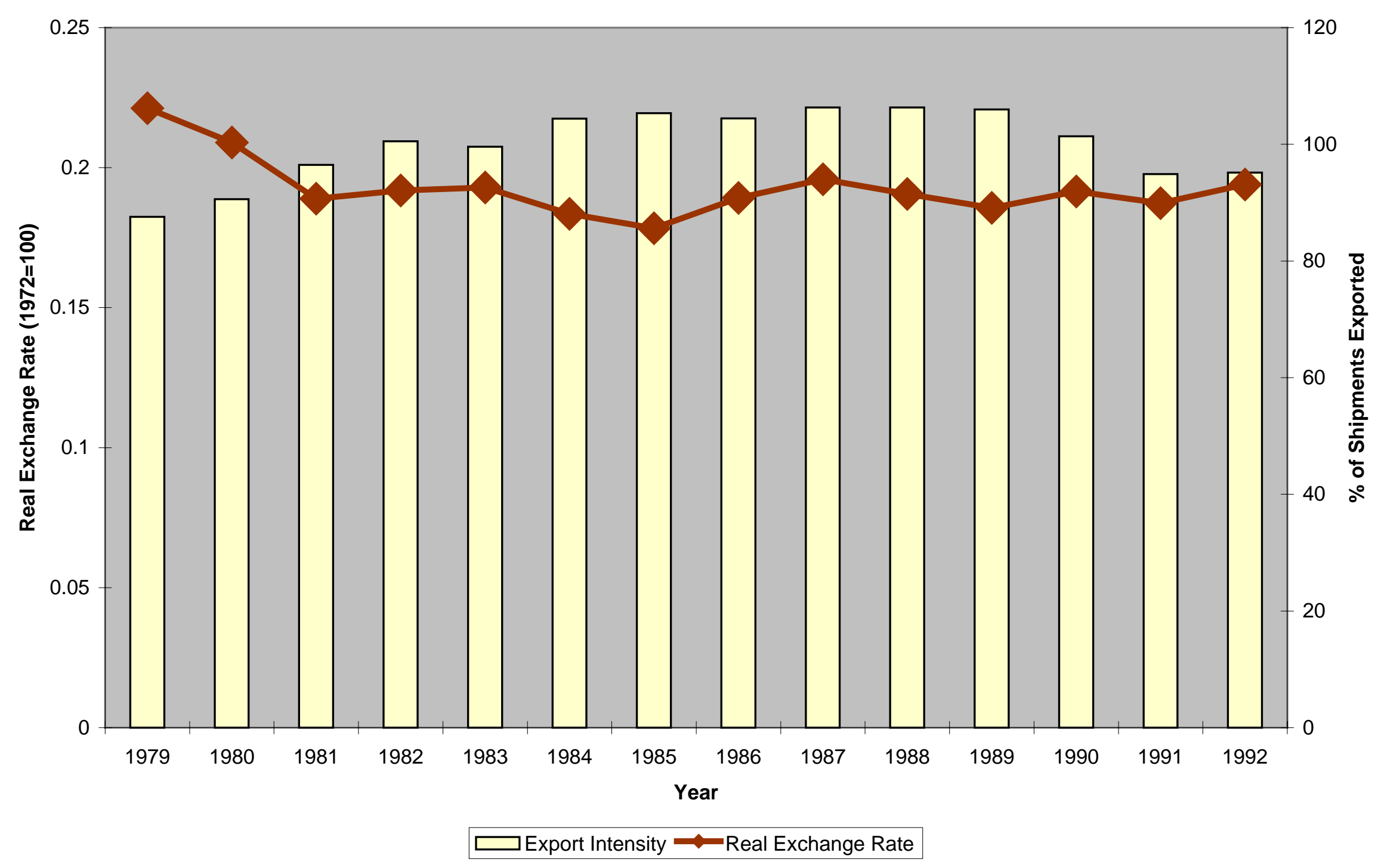

